\title{
A case of testicular germ cell carcinoma identified five years after lung metastasis resection
}

\author{
Hideki Kimura' ${ }^{1}$, Yukiko Matsui ${ }^{2}$, Yasumitsu Moriya ${ }^{2}$, Hajime Tamura², Aki I shikawa ${ }^{2}$, Toshihiko \\ I izasa $^{2}$, Masato Shingyoji ${ }^{2}$, Meiji I takura², Makiko I tami ${ }^{3}$, Takahiro Sugiyama ${ }^{3}$ \\ 1. Division of Thoracic Surgery, Saiseikai Narashino hospital, Chiba, Japan. 2. Division of Thoracic Diseases, Chiba Cancer \\ Center, Chiba Japan. 3. Division of Pathology, Chiba Cancer Center, Chiba, Japan.
}

Correspondence: Hideki Kimura, MD, PhD. Address: Saiseikai Narashino Hospital, Izumi-cho 1-1-1, Narashino City, Chiba, Japan. Email: h.kimura@chiba-saiseikai.com

Received: November 4, 2014

DOI : $10.5430 /$ jst.v4n4p18
Accepted: December 14, 2014 Online Published: December 18, 2014 URL: http://dx.doi.org/10.5430/jst.v4n4p18

\section{Abstract}

A 33 year-old man was referred to our center with swelling of the left scrotum. He underwent resection of the left testis, and pathological diagnosis indicated a germ cell tumor of that testis. His past history included lung cancer resection 5 years before the testicular surgery. Precise pathological reevaluation of the lung cancer using immunohistochemical methods indicated that the tumor originally diagnosed as lung cancer was a metastasis of the germ cell tumor of the left testis.

\section{Key words}

Carcinoma of unknown primary, Dormant tumor cells, Germ cell carcinoma, Lung metastasis, Immunotherapy

\section{Introduction}

Carcinoma of unknown primary (CUP) is defined as a biopsy-proven metastatic malignancy in which no primary tumor could be detected despite thorough diagnostic evaluation ${ }^{[1,2]}$. CUP accounts for approximately $3 \%$ of all head and neck squamous cell carcinomas. The mechanisms of CUP are surmised to be rapid growth of metastatic tumors resulting in clinically evident lesions while the primary tumor remains dormant, asymptomatic and undetectable by routine examinations. Dormant tumor cells may exist in a quiescent state for many years as solitary tumor cells (i.e., cellular dormancy) or as micro-primary lesions or micro-metastases whose cellular proliferation is counterbalanced by apoptosis (tumor mass dormancy) ${ }^{[3-5]}$. The diagnosis of CUP is not difficult when a tumor develops in a histologically heterotopic site, for example, adenocarcinoma in lymph nodes or bone marrow while the primary lesion is not detected for a relatively long period of time. However, it is very difficult if the metastasis grows in a histologically orthotopic site, as in the case of adenocarcinoma or squamous cell carcinoma in the lung. The present paper reports a case of a germ cell tumor of the left testis diagnosed 5 years after the resection of a pulmonary metastatic tumor.

\section{Case report}

In April 2006, a twenty-eight-year-old man was introduced to our cancer center with a primary lung adenocarcinoma of the left upper lobe (see Figure 1). No distant metastases were confirmed by routine examinations for lung cancer using 
computed tomography (CT), bone scan and brain magnetic resonance imaging (MRI). Left upper lobectomy and lymph node dissection were performed (see Figure 2) in May 2006. The post-surgical diagnosis was primary lung adenocarcinoma (T4N2M0 stage IIIB, PM1, No 5 lymph node metastasis; see Figure 3). He received adjuvant chemotherapy with 2 courses each of carboplatin (AUC5) + Paclitaxel $\left(200 \mathrm{mg} / \mathrm{m}^{2}\right)$ and of docetaxel $\left(60 \mathrm{mg} / \mathrm{m}^{2}\right)$ from July to November 2006. Adoptive immunotherapy was also given after the chemotherapy every one to two months with dendritic cells and activated killer cells cultured from non-metastatic regional lymph nodes in IL2 obtained at surgery ${ }^{\text {[6-10] }}$. The total course of immunotherapy consisted of 10 treatments performed between Nov 2006 and March 2008, the total number of cells transferred being $4.75 \times 10^{10}$.

Figure 1. CT shows left upper lobe tumor of $60 \mathrm{~mm} \times 57 \mathrm{~mm}$ in diameter.

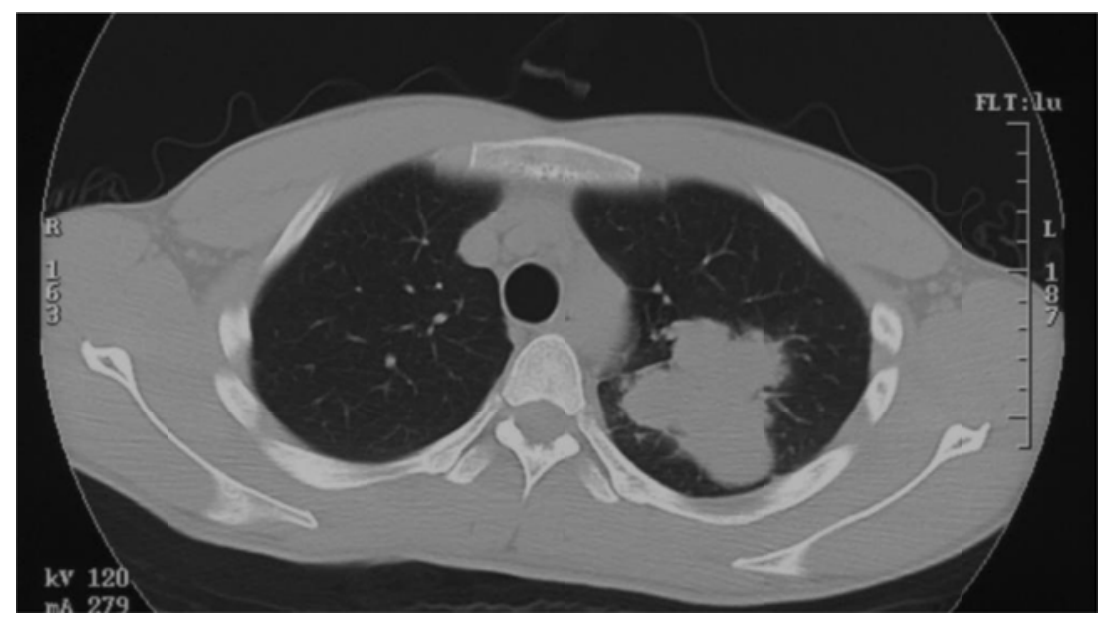

Figure 2. Macroscopic view of lung tumor. The tumor has 2 parts with clear viable and yellowish gray lesions separated by multiple septa. The margin is clear but uneven.

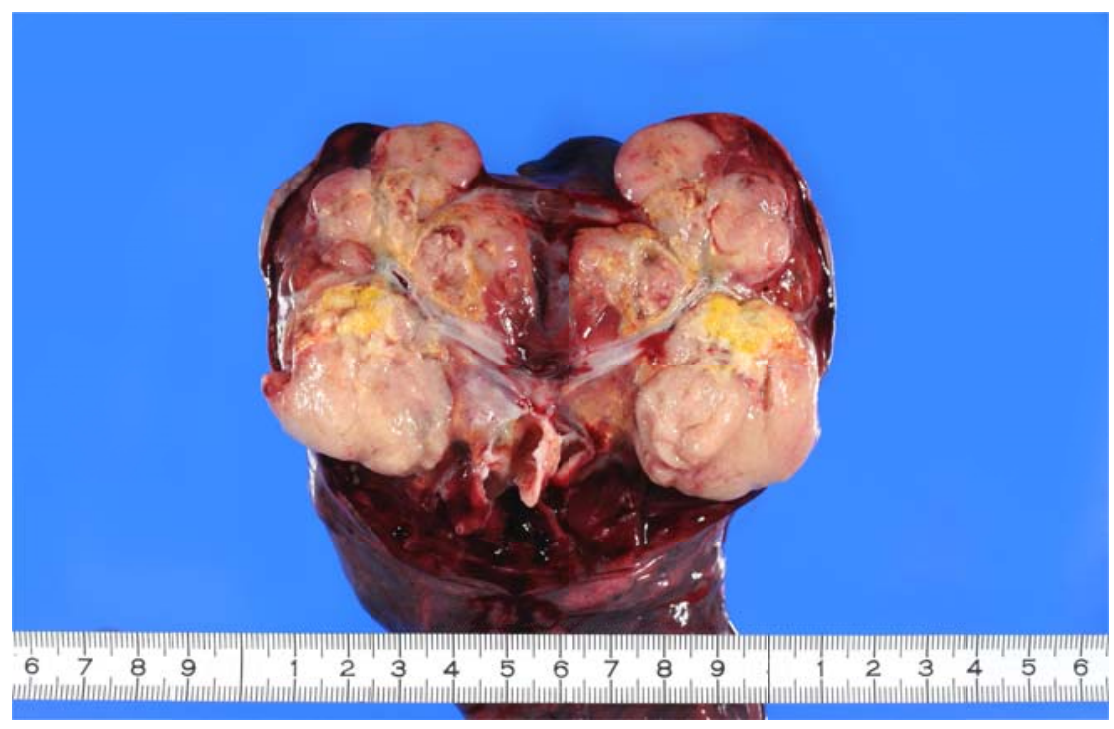

He visited our hospital every 2-3 months for 2 years after surgery and every 6 months thereafter. His condition was good and uneventful until he noticed a rapidly growing tumor in his scrotum in November 2011. The left testis was resected (see Figure 4). The diagnosis was a germ cell tumor of the left testis, mixed forms, pT1 embryonal carcinoma 70\% > yolk sac tumor 30\% (see Figures 5). Furthermore, reevaluation of the left lung tumor with an immunohistochemical procedure revealed AFP (+) (see Figure 6a), PE-10 (-) (see Figure 6b) and TTF-1 (-) (see Figure 6c). The final diagnosis of the lung tumor was metastatic lung carcinoma of the testis. 
Figure 3. Microscopic view of the lung. (Hematoxilin and eosin stain $\times 200$ ). Cuboidal and polygonal tumor cells with hyperchromatic nuclei are arranged in a papillary pattern. Enlarged nucleoli and mitosis are numerous. The diagnosis was poorly differentiated papillary adenocarcinoma.
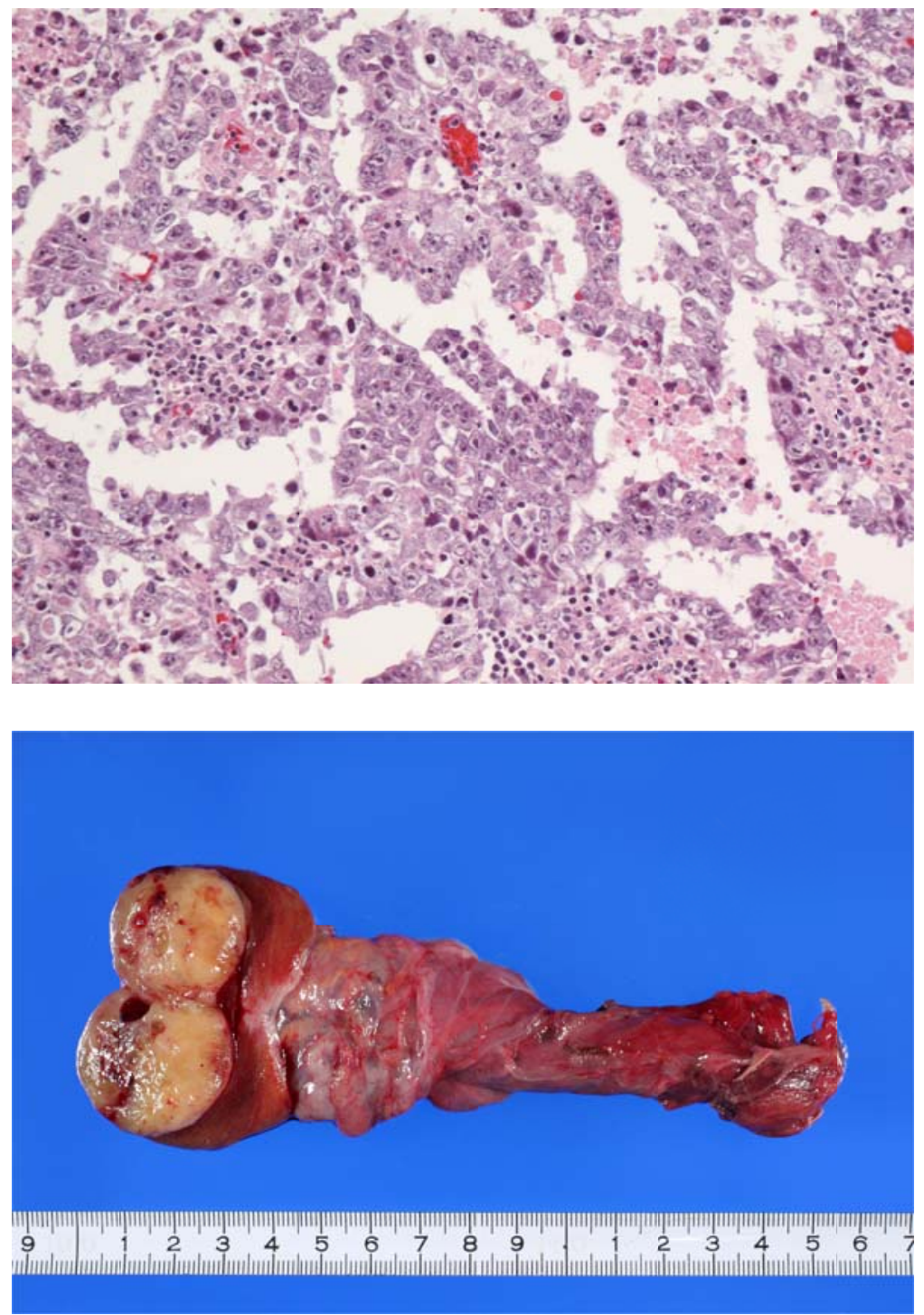

Figure 4. Macroscopic view of germ cell tumor of the left testis.
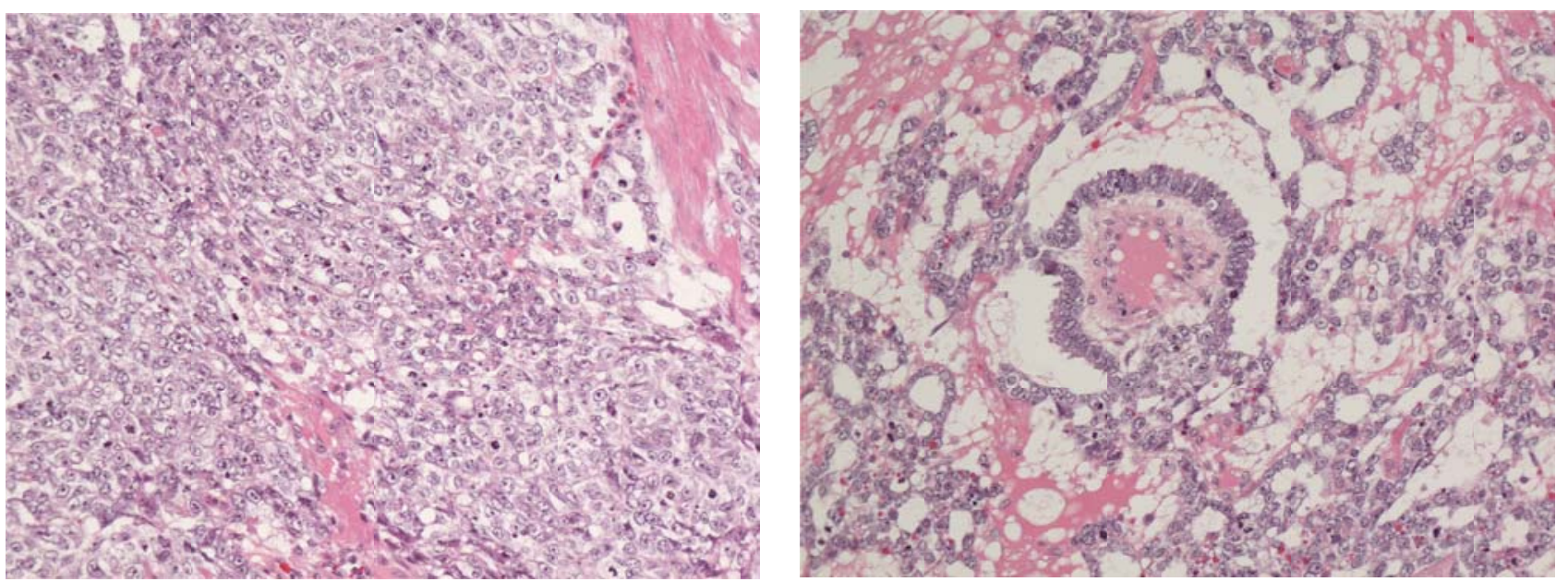

Figure 5. Germ cell tumor of the testis. Tumor cells with round to oval nuclei are arranged in a reticular and papillary pattern. Tumor cells are AFP stain positive (Yalk sac tumor 30\%). 

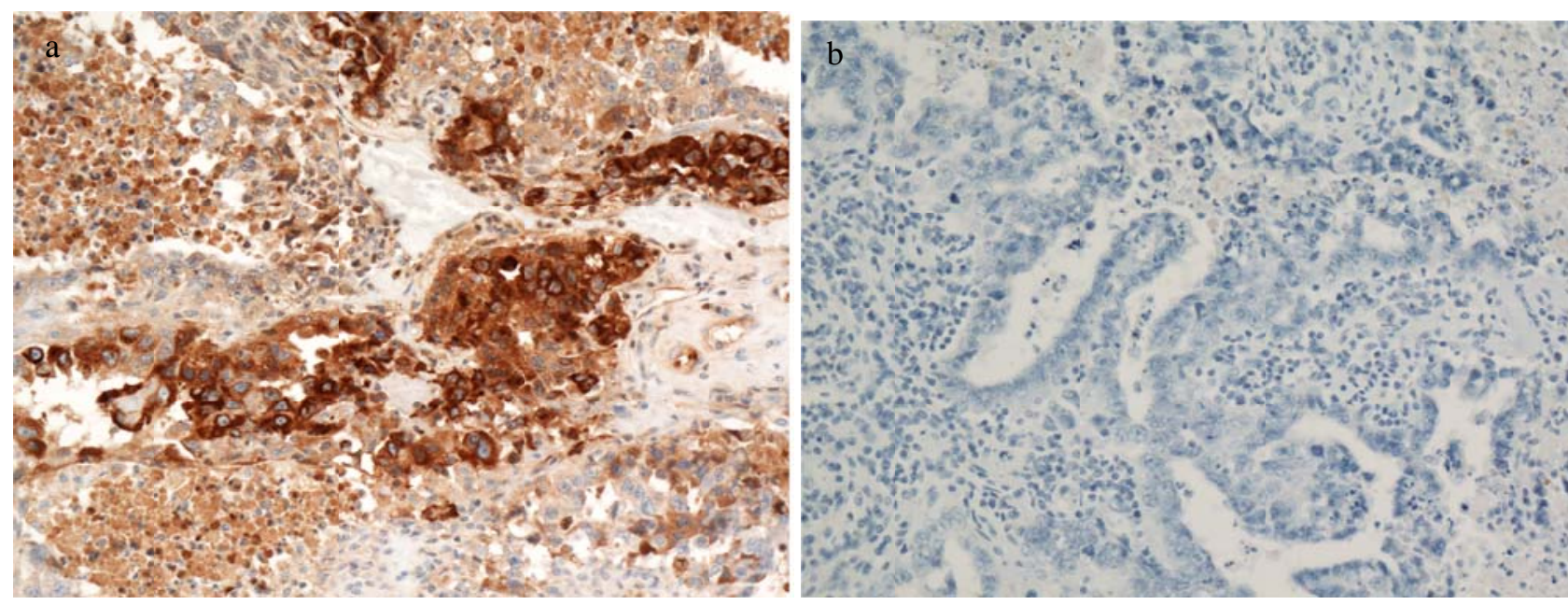

Figure 6. Immunohistochemical analysis of lung tumor. Tumor cells are stained with (a) AFP(+); (b) PE-10(-); (c) TTF-1 (-). Immunohistochemical stain indicated the lung tumor is a metastasis of germ cell tumor of the testis.

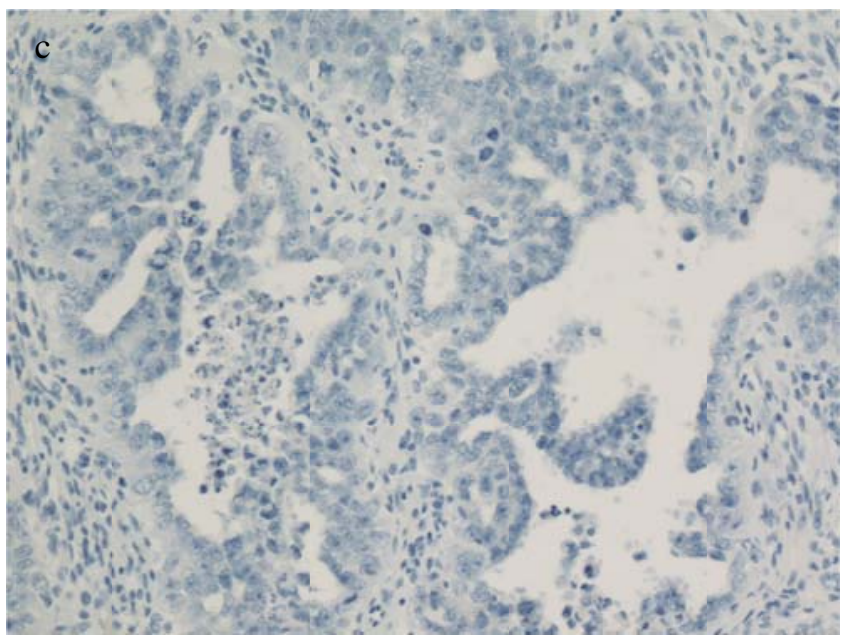

\section{Discussion}

Metastatic disease may occur years or even decades after successful treatment of the primary tumor by surgery or adjuvant treatment ${ }^{[11]}$. It has been proposed that this latency period is due to a clinical phenomenon known as tumor dormancy ${ }^{[3-5]}$. CUP is defined as a histologically proven metastatic malignancy in which the primary tumor could not be detected by routine diagnostic procedures ${ }^{[1,2]}$. This case should have been diagnosed as CUP until the disclosure of primary lesion. It was very difficult, however, to diagnose the present case as a metastasis since the histological diagnosis was adenocarcinoma of the lung which suggests a primary lung cancer. It is conceivable that the germ cell tumor metastasized to the lung in the relatively early stages of malignant transformation while the primary lesion remained dormant for more than 5 years. This case led us to consider several interesting clues concerning tumor dormancy and the formation of metastasis.

First of all, malignant tumors start shedding tumor cells from a very early stage of their growth, even during dormancy or clinically undetectable period ${ }^{[12,13]}$. In the present case, tumor cell shedding and metastasis formation started at least 5 years before the detection of the primary germ cell tumor in the left testis. Dormant tumor cells may exist in a quiescent state for many years as solitary cells (cellular dormancy) or as micro-primary or micrometastases whose cellular proliferation is counterbalanced by apoptosis (tumor mass dormancy) ${ }^{[14-16]}$. It is conceivable, in our case, that the primary germ cells, whose cellular proliferation was counterbalanced not only by apoptosis but also by the shedding of tumor cells, remained dormant. 
Secondly, there are two possible explanations for the apparent dormancy of the primary tumor and its fast-growing metastasis in the lung: 1) a proliferating subpopulation of the primary lesion metastasized to the lung, or 2) proliferation started after the dormant tumor cells arrested in the lung. The former may not be possible because the germ cell tumor in the testis would have appeared much earlier than 5 years before the resection of the metastasis. The general mechanisms that regulate the transition of dormant tumor cells into a proliferative state remain largely unknown. However, at least three mechanisms other than dormancy resulting from cell cycle arrest are suggested: 1) the interaction of the tumor cells with their microenvironment, the extracellular matrix, and with the stromal cells ${ }^{[17-20]}$; 2) limitation in the blood supply (angiogenic dormancy) ${ }^{[21-24]}$; and 3) an active immune system (immune surveillance). These three components have a close mutual correlation. Tumor progression not only requires the mutation necessary for malignant cell immortalization, transformation and amplification, but also is challenged by numerous intrinsic and extrinsic bottlenecks that can hold the tumor in its dormant stages for prolonged periods ${ }^{[3-5,14,15]}$.

Recent evidence indicates that tumor microenvironment is a critical regulator of cancer progression ${ }^{[17-20]}$ and a major factor in determining the survival and growth of circulating and disseminating tumor cells at preferential target sites ${ }^{[25,26]}$. It is conceivable that dormant tumor cells from the germ cell tumor of the testis migrated through the veins, adhered to the pulmonary arterial micro-capillary bed and arrested in the lung. The microenvironment of the lung may have been more suitable for dormant tumor cells to adapt, and may have activated the proliferation pathway. The blood supply is also important for rapid cell proliferation.

Immune competent cells have been suggested to eliminate circulating disseminating tumor cells from the body, however, in turn, the immune response assists tumor cell proliferation in certain conditions of tumor growth. There are two mutually conflicting effects in the immune response to tumor cells ${ }^{[27-31]}$ - inhibition (or suppression) and enhancement (or acceleration). When tumors are small or dormant, the immune response works to inhibit tumor growth or eliminate them from the body (immune surveillance). On the other hand, once a tumor develops into a clinically detectable mass, the immune response, in turn, enhances malignant cell growth.

As an adjuvant treatment for this patient, we used anticancer chemotherapy and adoptive immunotherapy ${ }^{[6-10]}$. These anticancer therapies may have not only eliminated other metastatic tumor cells, but also suppressed primary tumor cell proliferation. The dormant germ cell tumor was already present when the lung carcinoma was diagnosed in 2006, and the chemo-/immune-therapies might a possible reason to activate these "dormant" cells, leading to tumor formation after the influence of immune response.

In the study presented here, we learned several important details concerning tumor growth and metastasis: 1) tumor cells are released from a primary lesion in the relatively early stages of tumor progression, even at a dormant, clinically undetectable stage of cancer development; 2) tumor dormancy may have been induced by the balance of proliferating tumor cells and apoptosis or shedding of tumor cells from the primary lesion; 3) tumor growth is deeply dependent on the microenvironment. It must be realized that clinically detectable tumors are only a part of the overall dissemination and circulation of tumor cells in the body, and that tumor dormancy depends closely on the delicate balance of the tumor microenvironment, the immune response and angiogenesis.

\section{Acknowledgement}

We thank Mr. C.W.P Reynolds, associated with the Department of International Medical Communications, Tokyo Medical University, for his careful revision of the English of this manuscript.

\section{Conflicting interests}

The authors declare that there are no conflicting interests. 


\section{References}

[1] Pavlidis N, Fizazi K. Carcinoma of unknown primary (CUP). Crit Rev Oncol Hematol. 2009; 69: 271-8. PMid:18977667 http://dx.doi.org/10.1016/j.critrevonc.2008.09.005

[2] Blaszyk H, Hartmann A, and Bjornsson J. Cancer of unknown primary: clinicopathologic correlations. APMIS. 2003; 111: 1089-94. PMid:14678017 http://dx.doi.org/10.1111/j.1600-0463.2003.apm1111203.x

[3] Enderling H, Hahnfeldt P, Hlatky L, Almog N. Systems biology of tumor dormancy: linking biology and mathematics on multiple scales to improve cancer therapy. Cancer Res. 2012; 72: 2172-5. PMid:22414579 http://dx.doi.org/10.1158/0008-5472.CAN-11-3269

[4] Almog N.Molecular mechanisms underlying tumor dormancy. Cancer Lett. 2010; 28: 139-46. PMid:20363069 http://dx.doi.org/10.1016/j.canlet.2010.03.004

[5] Páez D, Labonte MJ, Bohanes P, Zhang W, Benhanim L, Ning Y, et al. Cancer dormancy: a model of early dissemination and late cancer recurrence. Clin Cancer Res. 2012; 18: 645-53. PMid:22156560 http://dx.doi.org/10.1158/1078-0432.CCR-11-2186

[6] Kimura H, Yamaguchi Y. Adjuvant chemo-immunotherapy after curative resection of Stage II and IIIA primary lung cancer. Lung Cancer. 1996; 14: 301-14. http://dx.doi.org/10.1016/0169-5002(96)00555-7

[7] Kimura H, Yamaguchi Y. A phase III randomized study of interleukin-2 lymphokine-activated killer cell immunotherapy combined with chemotherapy or radiotherapy after curative or noncurative resection of primary lung carcinoma. Cancer. 1997; 80: 42-9. http://dx.doi.org/10.1002/(SICI)1097-0142(19970701)80:1<42::AID-CNCR6>3.0.CO;2-H

[8] Kimura H, Dobrenkov K, Iida T, Suzuki M, Ando S, Yamamoto N. Tumor-draining lymph nodes of primary lung cancer patients: a potent source of tumor-specific killer cells and dendritic cells. Anticancer Res. 2005; 25: 85-94. PMid:15816523

[9] Kimura H, Iizasa T, Ishikawa A, Shingyouji M, Yoshino M, Kimura M, et al. Prospective phase II study of post-surgical adjuvant chemo-immunotherapy using autologous dendritic cells and activated killer cells from tissue culture of tumor-draining lymph nodes in primary lung cancer patients.Anticancer Res. 2008; 28:1229-38. PMid:18505060

[10] Hideki Kimura, Yukiko Matsui, Aki Ishikawa, Takahiro Nakajima, Mitsuru Yoshino, Yuichi Sakairi, et al. Randomized controlled phase III trial of adjuvant chemo-immunotherapy with activated killer T cells and dendritic cells in patients with resected primary lung cancer. Cancer Immunol Immunother. 2014. http://dx.doi.org/10.1007/s00262-014-1613-0

[11] Aguirre-Ghiso JA. Models, mechanisms and clinical evidence for cancer dormancy. Nat Rev Cancer. 2007; 7: 834-46. PMid:17957189 http://dx.doi.org/10.1038/nrc2256

[12] Pantel K, Schlimok G, Braun S, Kutter D, Lindemann F, Schaller G, et al. Differential expression of proliferation-associated molecules in individual micrometastatic carcinoma cells. J Natl Cancer Inst. 1993; 85: 1419-24. PMid:7688814 http://dx.doi.org/10.1093/jnci/85.17.1419

[13] Braun S, Vogl FD, Naume B, Janni W, Osborne MP, Coombes RC, et al. A pooled analysis of bone marrow micrometastasis in breast cancer. N Engl J Med. 2005; 353: 793-802. PMid:16120859 http://dx.doi.org/10.1056/NEJMoa050434

[14] Naumov GN, MacDonald IC, Chambers AF, Groom AC. Solitary cancer cells as a possible source of tumour dormancy? Semin Cancer Biol. 2001; 11: 271-6.

[15] Townson JL, Chambers AF. Dormancy of solitary metastatic cells. Cell Cycle. 2006; 5: 1744-50.

[16] Chambers AF, Groom AC, MacDonald IC. Dissemination and growth of cancer cells in metastatic sites. Nat Rev Cancer. 2002; 2: 563-72. PMid:12154349 http://dx.doi.org/10.1038/nrc865

[17] Fidler IJ. The organ microenvironment and cancer metastasis. Differentiation. 2002; 70: 498-505. PMid:12492492 http://dx.doi.org/10.1046/j.1432-0436.2002.700904.x

[18] Bissell MJ, Radisky DC, Rizki A, Weaver VM, Petersen OW. The organizing principle: microenvironmental influences in the normal and malignant breast. Differentiation. 2002; 70: 537-46. PMid:12492495 http://dx.doi.org/10.1046/j.1432-0436.2002.700907.x

[19] Hu M, Polyak K. Microenvironmental regulation of cancer development. Curr Opin Genet Dev. 2008; 18: 27-34. PMid:18282701 http://dx.doi.org/10.1016/j.gde.2007.12.006

[20] Schedin P, Elias A. Multistep tumorigenesis and the microenvironment. Breast Cancer Res. 2004; 6: 93-101. PMid:14979914 http://dx.doi.org/10.1186/bcr772

[21] Hanahan D, Folkman J. Patterns and emerging mechanisms of the angiogenic switch during tumorigenesis. Cell. 1996 ; 86: 353-64. http://dx.doi.org/10.1016/S0092-8674(00)80108-7

[22] Baeriswyl V, Christofori G. The angiogenic switch in carcinogenesis. Semin Cancer Biol. 2009; 19: 329-37.

[23] Udagawa T, Fernandez A, Achilles EG, Folkman J, D'Amato RJ. Persistence of microscopic human cancers in mice: alterations in the angiogenic balance accompanies loss of tumor dormancy. FASEB J. 2002; 16:1361-70. PMid:12205027 http://dx.doi.org/10.1096/fj.01-0813com 
[24] Holmgren L, O'Reilly MS, Folkman J. Dormancy of micrometastases: balanced proliferation and apoptosis in the presence of angiogenesis suppression. Nat Med. 1995; 1: 149-53. PMid:7585012 http://dx.doi.org/10.1038/nm0295-149

[25] Massagué J. New concepts in tissue-specific metastases. Clin Adv Hematol Oncol. 2003; 1: 576-7. PMid:16258451

[26] Pantel K, Brakenhoff RH, Brandt B. Detection, clinical relevance and specific biological properties of disseminating tumor cells. Nat Rev Cancer. 2008; 8: 329-40. PMid:18404148 http://dx.doi.org/10.1038/nrc2375

[27] Kimura H, Aoki T. Enhancing and inhibiting effects of spleen cells from tumor-bearing mice on growth of virus-induced primary sarcoma. Br J Cancer. 1978; 37:553-65. http://dx.doi.org/10.1038/bjc.1978.84

[28] Soucek L, Lawlor ER, Soto D, Shchors K, Swigart LB, Evan GI. Mast cells are required for angiogenesis and macroscopic expansion of Myc-induced pancreatic islet tumors. Nat Med. 2007; 13: 1211-8. PMid:17906636 http://dx.doi.org/10.1038/nm1649

[29] Shaked Y, Voest EE. Bone marrow derived cells in tumor angiogenesis and growth: are they the good, the bad or the evil? Biochim Biophys Acta. 2009; 1796(1): 1-4. PMid:19703646

[30] Hahnfeldt P, Panigrahy D, Folkman J, Hlatky L. Tumor development under angiogenic signaling: a dynamical theory of tumor growth, treatment response, and postvascular dormancy. Cancer Res. 1999; 59: 4770-5. PMid:10519381

[31] Moserle L, Amadori A, Indraccolo S. The angiogenic switch: implications in the regulation of tumor dormancy. Curr Mol Med. 2009; 9: 935-41. PMid:19925406 http://dx.doi.org/10.2174/156652409789712800 